\title{
Reappraisal of the role of dolasetron in prevention and treatment of nausea and vomiting associated with surgery or chemotherapy [Erratum]
}

Roberts SM, Bezinover DS, Janicki PK. Cancer Management and Research. 2012; 4: 67-73.

On the first page of the paper the incorrect DOI has been displayed. The correct DOI is: 10.2147/CMAR.S15545.

Cancer Management and Research is an international, peer-reviewed open access journal focusing on cancer research and the optimal use of preventative and integrated treatment interventions to achieve improved outcomes, enhanced survival and quality of life for the cancer patient. The manuscript management system is completely online and includes a very quick and fair peer-review system, which is all easy to use. Visit http://www.dovepress.com/testimonials.php to read real quotes from published authors. 